\title{
PENDIDIKAN KARAKTER KRISTEN DAN MODEL PEMBELAJARAN STAD DI KELAS MATEMATIKA DI SD KRISTEN "X" SURABAYA
}

\author{
Lacta Wida Rayu Cahyaningati*, Yuli Christiana Yoedo ${ }^{2}$ \\ Program Studi Pendidikan Guru Sekolah Dasar, Universitas Kristen Petra \\ Jl. Siwalankerto 121-131, Surabaya \\ E-mail: *lactaw1508@gmail.com; ²yulichy@petra.ac.id \\ *Penulis korespondensi
}

\begin{abstract}
ABSTRAK
Penelitian kualitatif ini dilakukan untuk mengetahui bagaimana guru menerapkan pendidikan karakter Kristen dan model pembelajaran STAD di kelas Matematika di SD Kristen "X" Surabaya. Teori yang dipakai adalah teori Lewis tentang pendidikan karakter Kristen. Subjek penelitian adalah Ibu Vitri dan teori Slavin tentang model pembelajaran kooperatif STAD. Data penelitian didapatkan dari tindakan dan perkataan guru kelas. Guru menerapkan 9 tahap penerapan model pembelajaran kooperatif tipe STAD, yaitu menyampaikan tujuan belajar, memotivasi murid, menyajikan informasi, mengorganisasikan murid dalam kelompok, membagikan rubrik penilaian, membagikan form penilaian sebaya, membimbing kelompok belajar, evaluasi, serta memberikan penghargaan. Guru memasukkan pendidikan karakter dengan melalui perenungan Firman untuk mendasari proses pembelajaran. Guru juga memberikan wejangan bahwa semua aktifitas dan tindakan (peduli, jujur, kerjasama) dilakukan untuk Tuhan. Cara terakhir adalah dengan melibatkan peran murid dalam pembentukan kelompok belajar, pencarian solusi dari masalah yang ditemukan, serta proses diskusi kelompok. Kesimpulan penelitian ini yaitu diperlukan penambahan 2 tahap penerapan model pembelajaran koopeartif tipe STAD, yaitu pembagian rubrik penilaian dan form penilaian sebaya, serta dengan memberikan pendidikan karakter Kristen untuk membuat Matematika menjadi kelas yang efektif dan bermakna di SD Kristen "X" Surabaya.
\end{abstract}

Kata kunci: Kejujuran, kepedulian, kesediaan bekerjasama, pendidikan karakter Kristen, model pembelajaran STAD.

\section{ABSTRACT}

This qualitative research is conducted to find out how teachers implement Christian character education and STAD learning models in Mathematics class at SD Kristen " $X$ " Surabaya. The theory that is used is Lewis's theory of Christian character education. The research subject was a teacher of class V-A and Slavin's theory of the STAD cooperative learning model. The research data were obtained from the actions and words of the class teacher. The teacher applies the 9 stages of implementing the STAD type of cooperative learning model, namely conveying learning objectives, motivating students, presenting information, organizing students in groups, distributing assessment rubrics, distributing peer assessment forms, guiding study groups, evaluating, and giving awards. The teacher incorporates character education through meditation on the Bible to base the learning process. The teacher also teaches that all activities and actions (caring, honesty, 
cooperation) are done for God. Finally, the teacher involves the students' roles in forming study groups, finding solutions to problems found, and in the group discussion process. The conclusion of this study is that it is necessary to add 2 stages to the application of the STAD cooperative learning model, namely the distribution of assessment rubrics and peer assessment forms, as well as by providing Christian character education to make Mathematics an effective and meaningful class in " $X$ " Christian Elementary School Surabaya.

Keywords: Caring, Christian character education, honesty, STAD learning model, willingness to collaborate.

\section{PENDAHULUAN}

Dilansir dari kemendikbud.go.id (2019) Indonesia saat ini sedang menyiapkan strategi pengembangan pendidikan di era globalisasi untuk mempersiapkan seluruh anak bangsa dalam menghadapi tantangan pendidikan abad-21 (salah diantaranya collaborative) dengan iman dan karakter yang baik. Hal ini sesuai dengan tujuan pendidikan nasional yang ada dalam UU No. 20 Tahun 2003 yang menyebutkan bahwa tujuan pendidikan bukan hanya untuk mengembangkan potensi akademik saja, namun juga pembentukan karakter murid. Lebih lanjut dijelaskan bahwa seluruh sekolah di Indonesia, baik negeri maupun swasta harus mampu menolong murid untuk mencapai tujuan pendidikan ini.

Semua subjek pelajaran yang ada di sekolah diharapkan dapat dijadikan sebagai pembelajaran yang dapat menolong murid untuk dapat mengembangkan sikap kolaboratif dan dapat mengembangkan karakterkarakter sesuai dengan imannya. Semua subjek mata pelajaran yang dimaksudkan adalah mata pelajaran yang dianggap mudah maupun mata pelajaran yang dianggap susah oleh murid. Dalam penelitian ini, peneliti memilih Matematika sebagai mata pelajaran yang akan diimplementasikan model pembelajaran kooperatif dengan mempertimbangkan bahwa Matematika adalah sebuah mata pelajaran yang ditetapkan sebagai mata pelajaran wajib bagi murid-murid yang duduk di tingkat Sekolah Dasar (SD), Sekolah Menengah Pertengah (SMP), dan Sekolah Menengah Atas (SMA). Dalam dunia pendidikan, Matematika acapkali dinilai sebagai mata pelajaran yang susah untuk dipahami. Dilansir dari tirto.id, hasil survei dari Indonesian National Assessment Program (INAP) oleh Pusat Penilaian Pendidikan Kementerian Pendidikan dan Kebudayaan (Kemendikbud) pada tahun 2018 memperlihatkan sebagian besar murid Sekolah Dasar di Indonesia kurang menyenangi mata pelajaran Matematika. Hanya 2,29\% murid yang masuk kategori gemar Matematika, 20,58\% termasuk ke dalam kategori biasa saja/netral, dan sebanyak $77,13 \%$ murid termasuk dalam kategori kurang gemar terhadap pelajaran Matematika.

Penelitian yang sama juga dilakukan oleh Zenius Education (2018) dengan responden sebanyak 1.340 murid sekolah dasar di Indonesia tentang alasan mengapa Matematika dinilai sebagai mata pelajaran yang tidak menarik minat. Hasil survei menyatakan bahwa (1) guru kelas yang galak dan menuntut untuk murid bekerja secara mandiri meskipun tidak mengerti materi; (2) materi Matematika terasa susah untuk dikerjakan sehingga murid malas menghafal rumus matematika yang terlalu banyak, serta (3) proses pembelajaran yang ada di dalam kelas terasa tidak berguna 
atau tidak ada kaitannya bagi kehidupan sehari-hari.

Salah satu cara yang dapat digunakan bagi guru untuk dapat menolong murid memiliki sikap berkolaboratif adalah dengan menggunakan model pembelajaran kooperatif. Pembelajaran kooperatif adalah metode pembelajaran dengan cara membentuk kelompok kecil yang mengutamakan kerjasama di antara murid untuk mencapai sebuah tujuan pembelajaran. Tujuan utama metode pembelajaran kooperatif adalah untuk membimbing keterampilan murid dalam bekerja serta untuk menumbuhkembangkan keterampilan berkolaborasi antar murid (Rianawati, 2014). Model pembelajaran kooperatif menekankan pada aktifitas dan interaksi di antara murid untuk saling memotivasi dan saling membantu dalam menguasai materi pelajaran guna mencapai prestasi yang maksimal.

Peneliti pernah melakukan penyebaran angket kuesioner kepada 18 murid kelas V-A di Sekolah Dasar "X" Surabaya terkait dengan penerapan metode kooperatif di kelas Matematika. Hasil survei ini menyatakan bahwa $68,75 \%$ murid kelas V-A sangat setuju dan $31,35 \%$ murid menyatakan setuju bila Matematika akan terasa mudah apabila dikerjakan secara berkelompok. Tidak ada satupun murid yang menyatakan ketidaksetujuan atas poin ini.

Dengan diterapkannya model pembelajaran kooperatif, diharapkan murid mampu untuk memiliki jiwa sosial yang tinggi ketika dewasa. Hal ini sejalan dengan teori yang dikemukakan oleh Vigotsky yang menyatakan bahwa perkembangan mental anak pada umumnya akan muncul lebih tinggi jika ada kerjasama antar individu sehingga dalam pengaplikasiannya diperlukan kondisi kelas yang kooperatif (dalam Rianawati, 2014). Salah satu tipe pembelajaran kooperatif adalah model pembelajaran STAD (Student Teams-Achievement Divisions). Model STAD ini pertama kali dikembangkan oleh Slavin. Pada model STAD ini, murid dibagi menjadi beberapa kelompok. Masingmasing kelompok terdiri dari 4 sampai 5 orang. Kegiatan pembelajaran dengan menggunakan metode STAD ini dibuka dengan penyampaian tujuan pembelajaran, penyampaian materi, lalu kegiatan berkelompok, serta ditutup dengan pemberian apresiasi kelompok. Menurut Slavin (dalam Isjoni, 2012) model pembelajaran STAD ini merupakan variasi dari pembelajaran kooperatif yang paling banyak diteliti dalam mata pelajaran Matematika, IPA, IPS, Bahasa Inggris, dan beberapa subjek lainnya di tingkat sekolah dasar.

Pembelajaran Matematika dengan model pembelajaran kooperatif STAD juga akan bermakna apabila dalam pelaksanaannya diintegrasikan dengan nilai-nilai Kekristenan. Menurut Saragih, Hidayat, \& Tamba (2019), melalui pengajaran Matematika dengan menggunakan model pembelajaran kooperatif STAD, guru perlu mengajak murid untuk mengembangkan keterampilan sosial dan kemampuan berpikir yang telah Tuhan berikan untuk dapat mengembangkan potensi dalam dirinya. Melalui penerapan model pembelajaran kooperatif guru dapat mengatur alur pembelajaran Matematika di kelas secara matang dan terstruktur bersama dengan teman kelompok. Dengan demikian di akhir pembelajaran Matematika, murid mampu menyadari bahwa dengan belajar Matematika, murid dapat mengasihi Tuhan dan mengasihi sesamanya melalui kerja sama selama proses pembelajaran berlangsung.

Penelitian ini akan dilakukan di Sekolah Dasar Kristen " $X$ " Surabaya. Peneliti memilih sekolah ini karena Sekolah Dasar Kristen " $X$ " Surabaya ini memiliki dedikasi 
Cahyaningati: Pendidikan Karakter Kristen dan Model Pembelajaran STAD di Kelas Matematika di SD Kristen "X" Surabaya Media Pembelajaran Taktil IPA Berbasis Alkitab Untuk Siswa Tunanetra Kelas 5 SD

untuk membangun generasi yang cerdas dan percaya diri. Sekolah Dasar Kristen " $X$ " ini juga memiliki kesungguhan untuk mendorong para muridnya untuk memperluas pikiran mereka secara ketat demi mempersiapkan murid dalam menghadapi kehidupan di Abad-21. Sekolah Dasar Kristen "X" Surabaya juga memperbekali setiap muridnya dengan keterampilan kolaborasi, komunikasi dan pemecahan masalah dikembangkan untuk mempersiapkan mereka untuk hidup dengan karakter Kristus, sehingga seluruh murid dapat tumbuh menjadi warga negara yang penuh kasih dan bertanggung jawab di dunia.

Sekolah Dasar Kristen “X” Surabaya ini memiliki visi yaitu membangun generasi yang bersinar yang mewujudkan karakter Kristus dan hidup di atas dasar Firman Allah. Tidak hanya itu misi yang sedang dijalankan oleh sekolah ini adalah mengembangkan nilai-nilai Kristen dalam diri murid dan mengilhami mereka untuk berjalan bersama Yesus; mendorong murid untuk berpikir kritis, memecahkan masalah secara efektif, menjadi kreatif, dan menjalani kehidupan yang didorong oleh tujuan; memotivasi murid untuk menjadi positif sepanjang kehidupan mereka dan mendasarkan keputusan mereka pada Firman Tuhan.

Subjek dari penelitian ini adalah seorang guru kelas V-A yang bernama Ibu Vitri karena beliau menerapkan metode pembelajaran kooperatif tipe STAD ketika mengajar. Hal ini sesuai dengan pernyataan wakil kepala sekolah bidang akademik Sekolah Dasar Kristen "X" Surabaya yang menyatakan bahwa "Oh jadi topiknya tentang metode STAD ya? Kebetulan Ibu Vitri memang menerapkan metode STAD sebagai salah satu metode pembelajaran ketika mengajar di kelas Matematika sih. Jadi saya rasa topiknya bisa diteliti di sekolah ini (Linda, personal communication, August 06, 2019)". Peneliti juga melakukan observasi lapangan serta melihat bahwa Ibu Vitri selalu membagi murid di dalam kelas menjadi beberapa kelompok belajar ketika mengajar Matematika. Selain itu, Ibu Vitri juga selalu mengaitkan Firman Tuhan yang disampaikan melalui devosi pagi dengan proses pembelajaran di dalam kelas Matematika dan guru kelas juga selalu memberikan arahan kepada murid untuk menjadi anak Tuhan Yesus yang saling menolong, jujur, dan memiliki kesediaan hati untuk bekerjasama. Hal ini yang kemudian juga menjadi poin keuinikan tersendiri dari proses pembelajaran di Sekolah Dasar Kristen " $X$ " Surabaya. Kemudian, peneliti juga melihat bahwa Ibu Vitri lebih banyak menggunakan metode pembelajaran kooperatif tipe STAD ketika mengajar Matematika.

Penelitian ini dilakukan untuk menjawab pertanyaan bagaimana guru menerapkan model pembelajaran kooperatif tipe STAD pada mata pelajaran Matematika Kelas V-A di Sekolah Dasar Kristen "X" Surabaya dan bagaimana guru memasukkan nilai-nilai pendidikan karakter Kristen pada mata pelajaran Matematika di Sekolah Dasar Kristen "X" Surabaya.

\section{LANDASAN TEORI}

\subsection{Model Pembelajaran Kooperatif Tipe STAD}

Menurut Slavin (dalam Isjoni, 2013, p.23), model pembelajaran kooperatif STAD (Student Teams-Achievement Division) merupakan sebuah pendekatan pembelajaran di mana guru akan mengelompokkan semua muridnya ke dalam beberapa kelompok kecil yang terdiri atas 4-5 orang. Pembelajaran kooperatif ini bertujuan agar murid dapat bekerjasama dalam kelompok dengan kemampuan maksimal yang dimiliki. Kemudian Hartanto, mengemukakan bahwa 
STAD adalah salah satu tipe dalam model pembelajaran kooperatif yang paling sederhana dan paling mudah untuk dapat diterapkan oleh guru (dalam Octavia, 2020). Lebih lanjut, Trianto (2009) mengemukakan bahwa model pembelajaran kooperatif tipe STAD merupakan model pembelajaran kooperatif dengan menggunakan kelompokkelompok kecil yang terdiri atas 4-5 orang murid heterogen dalam setiap kelompok.

Model pembelajaran kooperatif tipe STAD ini sesuai dengan keadaan dasar manusia yang tidak dapat hidup sendiri. Manusia cenderung untuk melakukan aktifitas sosial bersama dengan orang lain. Hal ini sesuai dengan teori dari Octavia (2020) yang menyatakan bahwa model pembelajaran kooperatif tipe STAD ini sesuai dengan keadaan alami manusia yang penuh dengan ketergantungan dengan orang lain, mempunyai tujuan serta tanggung jawab bersama yang ditandai dengan adanya pembagian tugas dan rasa susah senang bersama. Berdasarkan pemaparan diatas, maka peneliti mengambil kesimpulan bahwa model pembelajaran kooperatif tipe STAD adalah pendekatan pembelajaran dalam model pembelajaran kooperatif di mana guru mengelompokkan semua muridnya ke dalam beberapa kelompok kecil yang terdiri atas 4-5 orang yang heterogen dengan tujuan agar murid dapat membangun relasi, bertanggung jawab dan bekerjasama dengan teman sebaya.

Slavin (dalam Handayani, 2019) mengemukakan bahwa STAD memiliki ciri-ciri sebagai berikut :

1. Bahan pelajaran disajikan oleh guru dan murid harus mencurahkan perhatiannya karena hal itu akan mempengaruhi hasil kerja mereka dalam satu tim;

2. Setiap anggota kelompok terdiri dari empat atau lima orang yang heterogen dalam berbagai hal seperti prestasi akademik, jenis kelamin, status sosial, dan etnis;

3. Diadakan tes setelah satu atau dua kali pertemuan yang dikerjakan secara individu;

4. Guru menyiapkan Lembar Kerja Siswa (LKS);

5. Guru menentukan pembagian kelompok belajar murid.

Sugiyanto dan Sasongko (2008) menyebutkan ada beberapa langkah untuk melaksanakan model pembelajaran kooperatif tipe STAD. Langkah-langkah pembelajaran STAD yang dimaksud yaitu:

1. Guru menyampaikan materi pembelajaran kepada murid sesuai indikator yang harus dicapai pada hari itu. Setelah itu, guru memberikan motivasi kepada murid agar rasa ingin tahu mereka semakin muncul tentang materi yang akan dipelajari.

2. Guru membagi murid menjadi beberapa kelompok. Setiap kelompok terdiri dari 4-5 orang murid, di mana setiap anggota kelompok mempunyai kemampuan, suku budaya, serta jenis kelamin yang berbeda-beda.

3. Guru memberikan tugas kepada setiap kelompok. Pada fase ini, guru menjalankan fungsi sebagai pembimbing bagi setiap kelompok. Tidak hanya itu saja, guru juga memperhatikan kerja setiap kelompok. Hal ini dilakukan dengan tujuan agar guru dapat mengetahui sejauh mana pemahaman kelompok dan setiap murid terhadap materi yang diajarkan.

4. Guru mengevaluasi murid, baik secara kelompok maupun individu untuk mengetahui sejauh mana keberhasilan murid dalam belajar. Pada langkah ini, guru membuat penilaian bagi setiap anak berdasarkan perkembangan anak dan penilaian bagi tiap-tiap kelompok yang 
berdasarkan peningkatan belajar kelompok.

5. Guru memberikan penghargaan kepada kelompok yang memperoleh nilai tertinggi. Hal ini bertujuan agar murid dan kelompok dapat termotivasi untuk mencapai prestasi belajar yang maksimal.

Model pembelajaran kooperatif tipe STAD memiliki kelebihan dan kekurangan. Kelebihan dari model pembelajaran kooperatif tipe STAD dilihat melalui manfaat yang diberikan. Manfaat Model pembelajaran kooperatif tipe STAD dapat digolongkan menjadi manfaat jangka panjang dan manfaat jangka pendek. Soewarso (dalam Octavia, 2020) menyatakan bahwa manfaat jangka pendek dari model pembelajaran kooperatif tipe STAD adalah :

1. Membantu murid dalam mempelajari isi materi pelajaran yang sedang diperbincangkan;

2. Menghindari adanya nilai rendah dari murid;

3. Melatih keterampilan bekerjasama, berdiskusi, belajar untuk dapat menghargai pendapat orang lain, dan dapat belajar dari setiap anggota kelompok;

4. Membantu murid dalam mencapai tujuan belajar dan membangun relasi dengan teman sebaya;

5. Penghargaan yang diberikan oleh guru dapat dijadikan sebagai sebuah motivasi bagi murid untuk mencapai hasil yang lebih maksimal;

6. Mempermudah guru dalam melakukan monitoring kerjasama yang dilakukan murid di dalam proses pembelajaran.

Selain memiliki manfaat jangka pendek, model pembelajaran kooperatif tipe STAD juga memiliki manfaat jangka panjang. Menurut Nurhadi (dalam Octavia, 2020), manfaat jangka panjang dengan diterapkannya model pembelajaran kooperatif tipe STAD adalah murid dapat :

1. Meningkatkan kepedulian dan rasa kesetiakawanan,

2. Belajar tentang sikap, keterampilan, informasi, perilaku sosial, dan pandangan-pandangan baru,

3. Melakukan penyesuaian terhadap kondisi belajar dengan dibantu anggota kelompoknya,

4. Membentuk dan mengembangkan nilainilai sosial dan komitmen,

5. Mengikis sifat mementingkan diri sendiri,

6. Meningkatkan rasa percaya terhadap orang lain.

Meskipun model pembelajaran kooperatif tipe STAD memiliki kelebihan, namun model pembelajaran kooperatif tipe STAD juga memiliki kekurangan. Kekurangan diterapkannya model pembelajaran kooperatif tipe STAD menurut Mumtahanah (2018) adalah penerapan model pembelajaran tipe ini memerlukan waktu yang lama serta diperlukan peran yang baik dari guru sebagai motivator, evaluator, dan fasilitator.

\subsection{Pendidikan Karakter Kristen}

Menurut KBBI (2020), karakter diartikan sebagai tabiat; sifat-sifat kejiwaan, akhlak atau budi pekerti yang membedakan seseorang dengan yang lain; watak. Sucipto (2011) menyebutkan bahwa karakter merupakan nilai-nilai yang dimiliki oleh manusia, baik yang berhubungan dengan Tuhan Yang Maha Esa, maupun yang berhubungan dengan sesama manusia, lingkungan, dan kebangsaan. Karakter dalam diri seseorang akan tampak melalui pikiran, sikap, perasaan, perkataan, dan perbuatan berdasarkan norma-norma yang berlaku. Norma ini terkait dengan norma agama, hukum, tata krama, budaya, dan 
adat istiadat. Oleh sebab itu, karakter juga sering dikaitkan dengan sifat yang menjadi ciri khas atau kekuatan moral, atau tingkah laku seseorang.

Hartono (2014) menjelaskan bahwa karakter merupakan suatu proses memahat jiwa dan mengukir diri sedemikian rupa menjadi seseorang yang berbeda. Lebih lanjut dijelaskan bahwa jika dilihat berdasarkan Alkitab, definisi karakter adalah bagaimana cara seseorang menjalani hidup di hadapan Allah, takut hanya kepada Allah, dan berusaha hanya menyenangkan Tuhan, tidak peduli bagaimana perasaaan kita, atau apa yang mungkin akan dikatakan atau dilakukan orang lain. Dengan demikian, secara singkat karakter dapat diartikan sebagai cara melakukan apa yang benar karena hal itu benar di mata Allah.

Sutjipto (2011) menjelaskan bahwa pendidikan karakter dapat didefinisikan sebagai sebuah bantuan sosial agar setiap orang dapat bertumbuh dan menghayati kebebasannya dalam hidup bersama dengan orang lain. Suwito (2012) menyebutkan bahwa pendidikan karakter dapat dilakukan secara terpadu di dalam proses pembelajaran baik di dalam maupun di luar kelas. Pendidikan karakter ini bertujuan untuk menjadikan murid mampu menguasai kompetensi (materi) yang ditargetkan, serta untuk menjadikan murid mengenal, menyadari secara penuh, peduli, dan menjadikannya sebagai sebuah nilainilai yang ditunjukkan melalui perilaku murid sehari-hari.

Lebih spesifik, Koesoema (2010) menjelaskan bahwa pendidikan karakter Kristen diajarkan oleh guru bukan sekedar menjadikan murid untuk dapat memusatkan diri pada sisi duniawi dan manusiawi saja. Pendidikan karakter Kristen harus mampu memberikan jiwa dalam setiap proses pembelajaran yang ada sehingga proses pembelajaran yang ada dapat mengarah kepada pendidikan yang spiritualitas. Lebih lanjut dijelaskan bahwa kinerja untuk membangun karakter dalam lembaga pendidikan Kristen tidak sekedar menjadikan murid menjadi seseorang yang cakap dan pandai secara kognitif, namun juga bertujuan untuk menjadikan setiap murid menjadi seseorang yang beriman dan takut kepada Tuhan. Hal ini sejalan dengan Firman Tuhan yang mengatakan bahwa "permulaan hikmat adalah takut akan Tuhan dan mengenal Yang Mahakudus adalah pengertian" (Amsal 9:10). Berdasarkan pemaparan diatas, peneliti menyimpulkan bahwa pendidikan karakter jika dipandang dari kacamata pendidikan Kristen adalah sebuah cara dan strategi yang dilakukan oleh guru untuk membantu murid menjadi seseorang yang berilmu, beriman dan takut akan Tuhan Yesus.

Barbara A. Lewis (2004) dalam bukunya yang berjudul Character Building untuk Remaja dan Anak-anak menguraikan tentang nilai-nilai pendidikan karakter Kristen yang seharusnya ditanamkan oleh guru kepada murid. Berikut adalah nilainilai yang peneliti ambil untuk dijadikan fokus dalam penelitian kali ini :

\section{1) Peduli}

Di dalam kelas, guru mengajarkan nilai kepedulian kepada murid. Lewis (2004) menyatakan bahwa sikap peduli berbicara tentang bagaimana murid dapat memperlakukan teman dalam satu kelas agar mereka mau untuk berbagi, menolong, dan memberi. Sikap peduli ini dapat ditunjukkan melalui perkataan, perbuatan, pemikiran, dan pemberian. Sikap peduli yang dimiliki oleh setiap murid akan memampukan mereka bertumbuh dengan cara hidup yang tahu bagaimana cara memperhatikan sesamanya, serta peduli dengan permasalahan yang dihadapi oleh sesama. Sikap yang peduli ini, merupakan 
Cahyaningati: Pendidikan Karakter Kristen dan Model Pembelajaran STAD di Kelas Matematika di SD Kristen "X" Surabaya Media Pembelajaran Taktil IPA Berbasis Alkitab Untuk Siswa Tunanetra Kelas 5 SD

bagian dari nilai-nilai pendidikan karakter Kristen yang perlu untuk diimplementasikan oleh guru di dalam kelas.

Situru (dalam Lewis, 2004) menyatakan bahwa sikap peduli adalah perwujudan dari nilai kasih di dalam Alkitab. Di dalam Matius 22:39, Tuhan Yesus mengatakan bahwa manusia harus mengasihi sesamanya seperti mengasihi dirinya sendiri. Melalui ayat ini juga telah dijelaskan bahwa nilai kasih adalah hukum yang terutama di dalam kitab Taurat dan para nabi. Dengan demikian, dapat diketahui bahwa nilai kasih sangat penting untuk diajarkan bagi seluruh murid di sekolah.

Berikut adalah indikator yang dapat digunakan untuk melihat pengembangan nilai-nilai karakter kepedulian (Amasari, 2012) :

a. Memberikan pengertian dan wejangan kepada murid untuk saling menolong teman sebagai wujud kasih murid kepada sesama.

b. Menekankan bahwa Tuhan Yesus sangat mengasihi setiap manusia, sehingga setiap orang juga perlu untuk membagikan kasih Tuhan kepada sesamanya.

c. Memberikan perhatian kepada seluruh murid, termasuk terkait dengan absensi murid.

d. Menawarkan bantuan kepada murid untuk bertanya bagian materi yang belum dimengerti Menanyakan kabar murid.

e. Melerai murid yang sedang bertengkar.

f. Mengingatkan murid terkait durasi waktu pengerjaan tugas dan kerapian kelas.

2) Jujur

Kejujuran adalah nilai Kekristenan yang diajarkan oleh guru di sekolah. Lewis (2004) menyatakan bahwa kejujuran ini berbicara kebenaran apa adanya atau mengatakan segala sesuatu apa adanya mengenai suatu hal yang benar sesuai dengan kebenaran Tuhan di dalam Alkitab. Kejujuran membantu murid untuk dapat memiliki sikap yang dapat dipercaya oleh orang lain.

Di kelas, guru dapat mengajarkan nilai kejujuran ini kepada murid untuk dapat berbicara dan bertindak jujur sesuai dengan kebenaran yang ada. Dengan mengajarkan nilai kejujuran ini, murid dapat terhindar dari kebiasan mencontek ketika mengerjakan sesuatu. Hal ini sesuai dengan Firman Tuhan dalam Efesus 4:25 yang berkata bahwa "karena itu buanglah dusta dan berkatalah benar seorang kepada yang lain, karena kita adalah sesama anggota."

Berikut adalah indikator yang dapat digunakan untuk melihat pengembangan nilai-nilai karakter kejujuran (Amasari, 2012) :

a. Memberikan pengertian bahwa Tuhan Yesus menghendaki setiap orang berlaku jujur.

b. Sikap jujur merupakan perwujudan dari rasa hormat dan takut akan Tuhan Yesus,

c. Memperingatkan murid ketika mencontek temannya saat mengerjakan tugas atau saat ulangan/ujian.

d. Larangan membawa fasilitas komunikasi pada saat ulangan atau ujian.

e. Transparansi penilaian kelas.

3) Kerjasama

Kerjasama merupakan suatu usaha yang dilakukan oleh beberapa orang untuk mencapai tujuan pembelajaran. Menurut Isjoni (2013), kerjasama erat kaitannya dengan proses pembelajaran kooperatif. Pembelajaran kooperatif mengajarkan bahwa segala sesuatu dalam proses pembelajaran dilakukan secara bersamasama dengan saling menolong satu sama lain sebagai satu kelompok belajar. Ketika bekerja sama, murid diarahkan pada proses sosial untuk membangun ide dan 
mengembangkan kemungkinan solusi dari masalah yang dihadapi. Hal ini sejalan dengan Firman Tuhan dalam Pengkhotbah 4:9-10 yang menyatakan bahwa "berdua lebih baik daripada seorang diri, karena mereka menerima upah yang baik dalam jerih payah mereka. Karena kalau mereka jatuh, yang seorang mengangkat temannya, tetapi wai orang yang jatuh, tidak mempunyai orang lain untuk mengangkatnya"

Berikut adalah indikator yang dapat digunakan untuk melihat pengembangan nilai-nilai karakter kesediaan bekerjasama (Amasari, 2012) :

a. Saling membantu sesama anggota kelompok untuk menjelaskan materi kepada anggota kelompok yang belum memahami

b. Setiap anggota kelompok ikut memecahkan masalah dalam kelompok.

c. Berada dalam kelompok kerja saat kegiatan berlangsung.

d. Mengajak murid untuk membentuk kelompok belajar di kelas.

\section{METODE PENELITIAN}

\subsection{Desain Penelitian}

Penelitian yang dilakukan adalah jenis penelitian kualitatif. Penelitian yang akan dilakukan oleh peneliti bukanlah penelitian yang ditujukan untuk menguji suatu teori maupun sebuah hipotesis penguji, melainkan sebuah penelitian yang ditujukan untuk dapat menemukan atau mendapatkan sebuah teori melalui sebuah penelitian lapangan. Peneliti mengamati proses belajar mengajar pada mata pelajaran Matematika di Kelas V-A. Kemudian peneliti mencatat tindakan dan perkataan Ibu
Vitri selama mengajar mata pelajaran tersebut. Melalui penelitian ini, peneliti berusaha untuk menginterpretasikan dan kemudian melaporkan suatu fenomena yang ditemui ke dalam bentuk kata-kata tertulis.

Berdasarkan topik yang sudah terpilih, maka peneliti menggunakan metode kualitatif ini untuk meneliti permasalahan yang ditemukan. Peneliti mendeskripsikan bagaimana penerapan model pembelajaran kooperatif tipe STAD dan nilai-nilai Kekristenan pada mata pelajaran Matematika Kelas V-A di Sekolah Dasar Kristen "X" Surabaya (lihat Sarosa, 2012, dan Suwendra, 2018).

\subsection{Subjek Penelitian}

Subjek penelitian ini adalah seorang guru kelas V-A yang bernama Ibu Vitri, karena beliau terlibat secara langsung dalam menerapkan model pembelajaran kooperatif tipe STAD dan pendidikan karakter Kristen di kelas yang diampunya, yaitu kelas V-A di SD Kristen "X" Surabaya. Alasan kedua, yaitu bahwa Ibu Vitri bersedia untuk memberikan keterangan terkait topik penelitian.

\subsection{Metode dan Prosedur Pengambilan Data}

\subsubsection{Observasi}

Tujuan dari observasi ini adalah untuk mengamati dengan mendetail tindakan dan perkataan Ibu Vitri selama mengajar Matematika dengan menerapkan metode kooperatif tipe STAD dan nilai-nilai Kekristenan di Sekolah Dasar Kristen "X" Surabaya dan keadaan kelasnya (lihat John W. Creswell dan Hardiansyah, 2015). Selama melakukan observasi, peneliti menggunakan tabel observasi dan catatan pribadi untuk mencatat hasil observasi yang didapatkan di kelas. Tabel observasi ini terdiri dari fase-fase yang terdapat dalam proses penerapan metode kooperatif tipe STAD, di mana setiap poin dalam tabel pengamatan tersebut sudah diterapkan dengan nilai-nilai Kekristenan. 


\subsubsection{Wawancara}

Dalam penelitian ini, peneliti menggunakan teknik wawancara jenis semi terstruktur. Peneliti tidak menggunakan daftar wawancara, namun peneliti menggunakan pedoman wawancara yang digunakan sebagai acuan dalam membuat pertanyaan agar alur pembicaraan tidak keluar dari topik yang sudah ditentukan. Isi dari pedoman wawancara ini berbentuk poin-poin tema yang dipertanyakan, bukan pertanyaan kaku di mana peneliti hanya membaca pertanyaan saja. Dalam hal ini, peneliti bisa mengimprovisasi pertanyaaan tanpa keluar dari poin-poin tema yang telah ditentukan. Pertanyaan yang diberikan kepada narasumber bersifat terbuka.

Peneliti melakukan wawancara dengan Ibu Vitri dan Ibu Linda (informan) selaku wakil kepala sekolah bidang akademik di Sekolah Dasar Kristen " $X$ " Surabaya. Wawancara ini dilakukan melalui media online dengan menggunakan platform zoom meeting karena wabah COVID-19. Literatur atau penelitian mengenai penggunaan teknologi konferensi video online untuk pengambilan data kualitatif memang masih terbatas. Namun, dianggap hampir sama dengan pengambilan data melalui wawancara secara langsung karena memungkinkan interaksi real-time yang melibatkan suara, video, dan seringkali teks tertulis (lihat Archibald et al., 2019 dan Lo Iacono, Symonds, \& Brown, 2016; Sullivan, 2012; Weller, 2017, dalam Archibald et al., 2019).

\subsubsection{Penyebaran Angket atau Kuesioner}

Pengambilan data selanjutnya menggunakan angket kuesioner. Peneliti menyediakan pilihan jawaban, namun responden masih bisa untuk menuliskan deskripsi dari pilihan jawaban yang tersedia (lihat Gora, 2019). Peneliti menyebarkan angket kuesioner kepada murid kelas V-A. Penyebaran angket eval ini dibagikan secara online sebagai dampak adanya wabah COVID-19.

\subsubsection{Kepustakaan}

Peneliti mengumpulkan data melalui kajian literatur yang terkait dengan topik penelitian. Literatur ini berasal dari buku, karya ilmiah, skripsi, disertasi, jurnal, artikel, dan karya literatur lainnya. Hal ini dilakukan untuk mendapatkan teori yang mendasari dan juga data yang berkaitan dengan topik penelitian.

\subsubsection{Dokumentasi}

Metode pengambilan data selanjutnya berupa dokumentasi. Peneliti mengumpulkan data yang berupa foto kegiatan pembelajaran di dalam kelas, RPP, silabus, alat peraga, serta beberapa lembar lampiran dari hasil wawancara dan angket kuesioner di atas.

\subsection{Teknik Analisis Data}

Peneliti menggunakan tiga alur selama analisis data seperti yang dikemukakan oleh Miles, yaitu sebagai berikut :

\section{Reduksi Data (Data Reduction)}

Peneliti melakukan reduksi data dengan mengidentifikasi data mentah (raw data) yang telah diperoleh dengan membuat ringkasan, pengkodean, dan kategorisasi. Analisis ini dilakukan dengan menggolongkan dan mengorganisasi datadata hasil penelitian agar data yang didapatkan tetap terpusat pada tujuan penelitian yang ingin dicapai, dan memudahkan peneliti dalam membuat kesimpulan penelitian.

2. Penyajian Data

Peneliti menyajikan data dalam bentuk deskripsi. Data yang disajikan adalah seluruh informasi mengenai tindakan dan perkataan Ibu Vitri ketika mengajar Matematika menggunakan metode kooperatif tipe STAD dan nilai-nilai 
pendidikan karakter Kristen.

3. Penarikan Kesimpulan

Peneliti menarik kesimpulan dari kumpulan data yang telah disajikan. Kesimpulan tersebut merupakan jawaban dari rumusan masalah.

Pada tahap ini, peneliti menciptakan tema-tema atau kategori-kategori yang didasarkan pada kata-kata atau frase yang dihasilkan dari open coding. Kemudian peneliti membuat konsep atau gagasan teoritis yang berkaitan dengan kode dan tematema tersebut. Strategi yang tepat dalam proses analisis data ini adalah kemampuan

peneliti menghubungkan antara konsepkonsep yang telah dibuat dengan mengaitkan dengan teori-teori atau literatur-literatur yang telah ada.

\subsection{Uji Keabsahan Data}

Peneliti menggunakan metode triangulasi data dengan menggabungkan metode observasi, wawancara, angket kuesioner, dan dokumentasi. Pengabungan ini dilakukan untuk memperkecil kekurangan disetiap metode penelitian. Sehingga hasil data yang diharapkan dapat tetap valid dan reliable (lihat Sugiyono, 2013). Dengan memadukan sedikitnya tiga metode maka satu dan lain metode saling menutup kelemahan sehingga tangkapan atas realitas sosial menjadi lebih terpercaya.

Hasil dari transkripsi wawancara digunakan untuk memperjelas hasil temuan, sedangkan angket kuesioner menguatkan hasil temuan. Data yang diperoleh dari dokumentasi juga melengkapi hasil penelitian dalam bentuk visual. Dengan menggabungkan 4 metode, maka penelitian ini dapat valid dan reliable.

Peneliti menggunakan uji kredibilitas dengan melakukan perpanjangan pengamatan (prolonged engagement). Perpanjangan pengamatan ini dilakukan dengan sering masuk ke dalam kelas untuk melakukan pengamatan di Sekolah Dasar Kristen "X" Surabaya. Peneliti mengakhiri pengamatan pada tanggal 22 November 2019.

\section{ANALISA DATA}

\subsection{Cara Guru Memasukkan Nilai-Nilai Pendidikan Karakter Kristen pada Mata Pelajaran Matematika di Kelas VA SD Kristen X Surabaya}

Ada beberapa cara yang digunakan Ibu Vitri untuk memasukkan dan mengajarkan nilai-nilai pendidikan karakter Kristen dalam mata pelajaran Matematika. Cara yang digunakan adalah dengan perenungan Firman Tuhan melalui kegiatan morning devotion. Kegiatan morning devotion dilakukan sebelum Ibu Vitri memulai pembelajaran di kelas. Peneliti setuju karena Firman Tuhan merupakan dasar yang benar untuk membentuk karakter seseorang (lihat Hartono, 2014).

Menurut peneliti, morning devotion menjadi salah satu fokus sekolah untuk mengajarkan kebenaran Firman Tuhan dan membentuk karakter murid agar serupa dengan Tuhan Yesus sebab morning devotion membantu murid memahami keadaan alami manusia. Dengan demikian, pemberitaan Firman Tuhan melalui morning devotion baik untuk dilakukan (lihat Pane, 2019).

Melalui morning devotion, murid diberikan pengertian bagaimana cara menjalani kehidupan yang telah diperbaharui oleh kematian Kristus, yaitu dengan mentaati perintah Tuhan. Perintah Tuhan yang ditekankan adalah tentang kepedulian yang diterapkan selama proses pembelajaran sesuai dengan Kitab Markus 12:30-31 yang berkata "kasihilah Tuhan, Allahmu, dengan segenap hatimu dan dengan segenap jiwamu dan dengan segenap akal budimu dan segenap kekuatanmu. Dan hukum yang kedua ialah: Kasihilah sesamamu manusia 
seperti dirimu sendiri. Tidak ada hukum lain yang lebih utama dari pada kedua hukum ini."

Peneliti setuju bahwa perenungan Firman Tuhan dilakukan pada waktu pagi hari, karena murid lebih berkonsentrasi pada 15-20 menit pertama (lihat Rooijakker, dalam Dimyati \& Mudjiono, 2009). Ibu Vitri menanamkan nilai pendidikan karakter Kristen tentang kepedulian, kejujuran, dan kesediaan bekerja sama secara lisan. Dengan demikian, murid memahami bahwa guru sedang mengajarkan karakter tertentu kepada mereka (lihat Amasari, 2012).

Ibu Vitri menanamkan karakter pada murid dengan melibatkan murid secara langsung ke dalam tindakan yang merupakan pengamalan nilai karakter yang sedang diajarkan (lihat Tarigan, dalam Amasari, 2012).

Dalam menanamkan nilai ketiga karakter melalui model pembelajaran kooperatif tipe STAD, Ibu Vitri menerapkan pilar pendidikan Kristen. Pilar tersebut adalah Creation, Falling, Redemption, Consummation/CFRC (penciptaan, kejatuhan, penebusan, penggenapan). Menurut peneliti, menerapkan pilar CFRC baik untuk dilakukan. Dengan menerapkan pilar CFRC, murid terbantu memiliki cara pandang hidup yang benar untuk menjalani kehidupan yang diberikan oleh Tuhan dengan penuh kasih dan tanggung jawab (lihat Welchel, dalam Soekarmini, 2016).

Tantangan dan hambatan yang ditemukan adalah bagaimana mendorong murid mau belajar Firman Tuhan dengan setia. Strategi yang digunakan untuk meminimalisir tantangan dan hambatan tersebut adalah dengan cara selalu mengingatkan murid untuk selalu belajar Firman Tuhan setiap saat. Menurut peneliti, strategi yang digunakan tidak sekedar hanya mengingatkan murid melalui perkataan saja, namun dengan membiasakan murid membaca Firman Tuhan setiap hari dan menuliskan refleksi diri mereka ke dalam buku catatan khusus mereka. Hal ini dapat menjadikan murid terbiasa untuk membaca Alkitab. Kebiasaan jika dipelihara dengan baik menjadi gaya hidup murid tersebut. Dengan demikian murid dapat memiliki gaya hidup membaca Firman Tuhan (lihat Zhan \& Setiawan, 2018).

\subsection{Penerapan Model Pembelajaran Kooperatif Tipe STAD Pada Mata Pelajaran Matematika Kelas VA di SD Kristen X Surabaya}

Ada beberapa tahap yang dilakukan oleh Ibu Vitri ketika menerapkan model pembelajaran kooperatif tipe STAD. Tahap pertama yang dilakukan oleh guru adalah menyampaikan tujuan belajar. Tujuan pembelajaran disampaikan oleh guru di awal kelas secara jelas. Menurut peneliti tujuan pembelajaran perlu disampaikan di awal pembelajaran. Hal ini dapat membantu murid untuk dapat memahami pembelajaran yang mereka jalani serta menyiapkan diri untuk mengikuti pembelajaran dari awal. Dengan kesiapan diri murid sejak awal pembelajaran, murid lebih mudah untuk mengikuti proses pembelajaran sampai akhir dengan baik (lihat Gintings, 2010).

Tujuan pembelajaran dirancangkan sebelumnya oleh guru secara jelas agar dapat mempermudah guru untuk menciptakan tolok ukur yang nantinya digunakan dalam tahap evaluasi pembelajaran (lihat Suryosubroto, dalam Nur, Halidjah \& Tampubolon, 2015).

Ibu Vitri menjelaskan kepada setiap murid bahwa Tuhan Yesus telah menciptakan setiap murid secara unik dan berharga. Dalam hal ini, tindakan yang dilakukan oleh Ibu Vitri adalah memberikan pengertian bahwa setiap manusia 
merupakan gambar dan rupa Allah. Hal ini terdapat dalam Kitab Kejadian 1:27 yang berbunyi "maka Allah menciptakan manusia itu menurut gambar-Nya, menurut gambar Allah diciptakan-Nya dia; laki-laki dan perempuan diciptakanNya mereka."

Keberadaan alami manusia diciptakan segambar dan serupa dengan Allah membawa setiap murid saling mengasihi dan menghargai keberadaan teman mereka (lihat Naugle, dalam Nugroho, 2020). Menurut peneliti, penjelasan ini yang perlu ditambahkan oleh Ibu Vitri kepada murid pada saat membimbing kelompok belajar. Dengan demikian, setiap murid mengerti alasan dasar mengapa mereka perlu mengasihi dan menghargai orang lain.

Ketika menyampaikan tujuan belajar, Ibu Vitri menyebutkan tujuan pembelajaran adalah untuk mengerjakan latihan soal, membuat karya dari balok atau kubus, dan lain sebagainya. Menurut peneliti, penyampaian tujuan belajar secara Kristen juga harus dilakukan untuk membantu murid memahami bahwa tujuan utama mereka belajar Matematika adalah untuk mengerjakan tanggung jawab mereka sebagai ciptaan Tuhan yang selalu ingin diperbaharui secara akal budi (lihat Gulo, 2020).

Tahap kedua yang dilakukan oleh Ibu Vitri adalah memotivasi murid. Pemberian motivasi kepada murid di awal pembelajaran ini penting, karena motivasi berfungsi untuk menggerakkan, mengarahkan dan memacu semangat murid dalam belajar (lihat Woodwort, dalam Wina Sanjaya, 2010).

Peneliti setuju dengan tindakan Ibu Vitri memberikan motivasi di awal pembelajaran karena dapat membuat murid untuk melakukan kegiatan sehingga tujuan pembelajaran tercapai.

Peneliti setuju bahwa motivasi berpengaruh pada keberhasilan proses pembelajaran di kelas. Pemberian motivasi penting dilakukan oleh guru karena keberhasilan proses belajar mengajar bergantung pada motivasi belajar murid (lihat Wina Sanjaya, 2010).

Peneliti menemukan pemberian motivasi kepada murid dapat dilakukan dengan kalimat penguatan, permainan, hadiah di akhir kelas, nilai serta dengan menunjukkan raut muka yang semangat kepada murid. Peneliti melihat bahwa pemberian kalimat motivasi yang diberikan oleh guru selalu sama, yaitu untuk meyakinkan bahwa murid dapat mengerjakan soal yang diberikan serta memotivasi agar murid berani untuk bertanya. Menurut peneliti, guru perlu untuk memberikan motivasi terkait dengan pentingnya belajar Matematika. Ketika murid mengerti bahwa belajar Matematika itu berguna bagi kehidupannya, murid termotivasi untuk belajar Matematika dengan senang (lihat Uno, 2011).

Hal inilah yang kemudian dapat membangun atmosfir kelas yang menyenangkan. Menurut peneliti, pemberian motivasi dengan kata-kata, permainan, hadiah, nilai, serta raut muka guru dapat digolongkan ke dalam pemberian motivasi ekstrinsik (lihat Sudirman, 2000)

Selama peneliti mengamati proses pembelajaran yang ada di kelas V-A, peneliti tidak menemukan pemberian penghargaan kepada murid. Hal ini karena penghargaan hanya diberikan apabila ada kegiatan lomba yang melibatkan kelas lain. Menurut peneliti, sebaiknya pemberian penghargaan dilakukan pada akhir periode kelompok belajar. Misalnya dengan memberikan predikat "Group Terkompak" atau lain sebagainya. Pemberian penghargaan semacam ini dapat membuat kelompok belajar terpacu untuk mempertahankan predikat tersebut (lihat 
Skiner, dalam Andriyani, 2015).

Tahap ketiga yang dilakukan oleh Ibu Vitri adalah menyajikan informasi. Informasi yang disajikan oleh guru adalah informasi terkait kegiatan apa yang akan dilakukan pada pertemuan tersebut, misalnya mengerjakan latihan soal, membuat kerajinan tangan, dan lain sebagainya. Menurut peneliti penyajian informasi ini penting karena hal ini membuat murid memiliki pemahaman yang lebih jelas terkait apa yang mereka lakukan. (lihat Uluul, dkk, 2016).

Menurut peneliti, Ibu Vitri menyampaikan informasi pembelajaran dengan bahasa yang mudah dimengerti oleh murid dan tidak terlalu formal. Dengan demikian, murid dapat memahami instruksi atau gambaran kegiatan yang diberikan oleh guru. (lihat Sukmadinata, 2005). Selain itu, menurut peneliti, guru telah menyampaikan informasi dengan kalimat yang singkat dan tidak berbelit-belit. Pemberian informasi dengan singkat dan jelas ini membantu murid lebih mudah untuk memahami informasi yang disampaikan oleh guru (lihat Sukmadinata, 2005).

Selain menyampaikan gambaran tentang kegiatan yang akan dilakukan, Ibu Vitri juga memaparkan informasi terkait materi yang dipelajari oleh murid pada pertemuan itu. Materi yang disampaikan oleh Ibu Vitri yang menjadi topik pembahasan utama. Peneliti menilai bahwa kegiatan menjelaskan materi ini penting dilakukan. Hal ini karena pada saat menjelaskan materi, murid terbimbing untuk dapat memahami ilmu pengetahuan dengan baik (lihat Suherman, 2018).

Materi yang disampaikan oleh Ibu
Vitri adalah materi yang bersifat ulasan materi dari pertemuan sebelumnya dan atau materi yang sama sekali baru bagi murid. Peneliti sepakat dengan tindakan yang dilakukan oleh guru karena meskipun materi sudah pernah diberikan sebelumnya, namun masih ada kemungkinan murid untuk tidak mengingat materi tersebut. Selain itu, dengan adanya pengulasan materi pada pertemuan sebelumnya dapat menolong murid untuk memahami bahwa antara materi pembelajaran yang pernah disampaikan ada kaitannya dengan materi yang dibahas (lihat Ullul, dkk, 2016). Jika masuk dalam bab pembahasan baru yang tidak ada kaitannya dengan bab sebelumnya, Ibu Vitri tidak memberikan kaitan dengan materi yang sebelumnya.

Peneliti setuju dengan Ibu Vitri dalam penggunaan kisah Alkitab untuk menjelaskan konsep-konsep dalam Matematika. Istilah ini biasa dikenal dengan tahapan referencing the Bible, di mana guru melakukan pendekatan pembelajaran dengan menggunakan referensi cerita dari Alkitab. Hal ini membantu murid untuk belajar kebenaran Firman Tuhan ketika belajar Matematika (lihat Smith, dalam Adhi, Winardi, Listiani, 2018).

Dalam menyampaikan materi, Ibu Vitri tidak selalu mengaitkan dengan kehidupan nyata murid. Menurut peneliti, hal ini yang perlu ditambahkan dalam proses penyampaian materi. Hal ini karena ketika murid menyadari bahwa materi yang sedang mereka pelajari ada kaitannya dengan kehidupan nyata mereka, murid mengerti bahwa hal yang sedang mereka pelajari saat itu berguna bagi kehidupannya (lihat Fuadi, 2016).

Selama memaparkan materi, Ibu Vitri memberikan kesempatan murid untuk bertanya kapanpun sesuai dengan kesepakatan kelas yang telah disusun sebelumnya. Hal ini membantu setiap murid agar segera mengungkapkan pertanyaan yang mereka miliki sebelum mereka melupakannya. Pertanyaan murid 
langsung dijawab oleh guru yang mengajar. Peneliti setuju bahwa dengan memberikan kebebasan untuk bertanya dapat membantu murid lebih aktif ketika mengikuti kelas Matematika (lihat Sudjana, 2010).

Ibu Vitri menggunakan berbagai media pembelajaran selama memaparkan materi. Media pembelajaran yang digunakan adalah media pembelajaran berbasis visual, audio, serta audiovisual. Penggunaan media belajar yang bervariasi digunakan untuk memudahkan murid memahami materi sesuai dengan gaya belajar masing-masing murid. Hal ini karena tidak ada satu media pembelajaran yang lebih baik dari media pembelajaran yang lain. Oleh sebab itu keberagaman media pembelajaran dapat digunakan oleh guru untuk memfasilitasi gaya belajar murid yang berbeda-beda (lihat Nasution, 2008).

Tahap keempat yang dilakukan oleh Ibu Vitri adalah mengorganisasikan murid dalam kelompok. Setiap kelompok belajar beranggotakan 4-5 orang murid. Tujuan dari pembentukan kelompok belajar yang heterogen adalah agar murid dapat menerima kekurangan diri sendiri dan kekurangan yang dimiliki oleh setiap anggota kelompok (lihat Slavin, dalam Sanjaya, 2006).

Ketika melakukan pembagian kelompok, Ibu Vitri juga melakukan inovasi yaitu melibatkan peran murid. Dengan melibatkan peran murid, murid dapat merasa nyaman saat belajar. Perasaan nyaman yang dimiliki oleh murid menolong murid berproses untuk mencapai fokus tujuan belajarnya sehingga hasil belajar yang dihasilkan juga lebih maksimal (lihat Isjoni, 2009 dan Hamdani, 2011).
Inovasi lain yang dilakukan oleh Ibu Vitri adalah melakukan pergantian kelompok. Pergantian kelompok dilakukan dalam waktu beberapa minggu sekali. Hal ini sedikit berbeda dari teori yang dikemukakan oleh Slavin yang menyatakan bahwa ketika menerapkan model pembelajaran STAD, guru selalu melakukan pembentukan kelompok di setiap pertemuan. Pergantian kelompok belajar dalam pembelajaran tematik dapat diubah setelah menyelesaikan satu tema secara tuntas (lihat Ibrahim, dkk, 2000).

Pergantian kelompok semacam ini memberikan keuntungan tersendiri baik bagi guru maupun murid. Dari sisi guru, guru dapat melihat perkembangan perkembangan murid secara fokus selama satu tema. Sebaliknya dari sisi murid, murid tidak perlu bingung memikirkan kelompok belajar mana yang bekerjasama dengannya saat membahas materi A, B, atau $\mathrm{C}$ dalam satu tema.

Jika dilihat dari sudut pandang Alkitab, tindakan Ibu Vitri bertujuan untuk menolong murid mengerti akan panggilan hidup mereka sebagai ciptaan yang segambar dan serupa dengan Tuhan untuk menolong sesamanya. Hal ini sesuai dengan Firman Tuhan dalam Galatia 6:3 yang menyatakan agar kita dapat saling "bertolong-tolonglah menanggung bebanmu! Demikianlah kamu memenuhi hukum Kristus." (lihat Brummelen, dalam Gulo, 2020).

Tahap kelima yang dilakukan oleh Ibu Vitri adalah membagikan rubrik penilaian kepada setiap kelompok. Tahap membagikan rubrik penilaian tidak masuk dalam langkah-langkah penerapan model pembelajaran kooperatif tipe STAD yang dikemukakan oleh Slavin. Dengan demikian peneliti menilai bahwa tahap ini merupakan tahapan inovasi yang dilakukan oleh guru. Murid perlu mengetahui standar penilaian seperti apa yang sedang mereka jalani (lihat Wibowo, 2016).

Pembagian rubrik penilaian membantu murid memahami bagaimana guru 
Cahyaningati: Pendidikan Karakter Kristen dan Model Pembelajaran STAD di Kelas Matematika di SD Kristen "X" Surabaya Media Pembelajaran Taktil IPA Berbasis Alkitab Untuk Siswa Tunanetra Kelas 5 SD

mengevaluasi mereka, serta kemampuan apa yang diharapkan oleh guru. Dengan kata lain, rubrik penilaian ini digunakan untuk memberikan gambaran kepada murid tentang kriteria guru dalam memberikan menilai kelompok (lihat Wibowo, 2016).

Tahap keenam yang dilakukan oleh Ibu Vitri adalah membagikan format penilaian sebaya. Tahap pembagian format penilaian sebaya tidak termasuk dalam tahapan penerapan model pembelajaran kooperatif STAD yang dikemukakan oleh Slavin. Meskipun demikian, menurut peneliti tahap ini perlu untuk dilakukan. Hal ini karena dengan melakukan penilaian sebaya, murid diberi kepercayaan untuk menilai orang lain (lihat Syahrul, 2015).

Dalam melakukan penilaian sebaya, Ibu Vitri perlu menjelaskan kepada murid bahwa penilaian dilakukan secara objektif agar murid terbiasa menilai sesuatu secara otentik (lihat Hidayat, 2018). Hasil penilaian sebaya ini dapat memotivasi murid untuk berubah berdasarkan penilaian yang diterima (lihat Wijayanti, 2017).

Tahap ketujuh yang dilakukan oleh Ibu Vitri adalah membimbing kelompok belajar dengan membagikan lembar kerja murid. Lembar kerja tersebut berjumlah sama dengan jumlah anggota dalam kelompok. Hal ini bertujuan untuk membangun sikap kemandirian dari setiap murid (lihat Prastowo, 2012).

Pada tahap ketujuh ini, Ibu Vitri menerapkan peran sebagai pembimbing agar suasana belajar menolong murid untuk aktif berdiskusi (lihat Khun, 2000). Pada tahap ini, guru membantu kelompok belajar yang mengalami kesulitan dalam mengerjakan soal. Hal ini dilakukan dengan membimbing setiap kelompok untuk menemukan jalan keluar dari permasalahan yang mereka hadapi (lihat Sardiman, 2011).

Tahap kedelapan yang dilakukan oleh Ibu Vitri adalah memberikan evaluasi terhadap hasil pekerjaan kelompok belajar. Evaluasi dilakukan untuk mengetahui sejauh mana murid memahami pembelajaran yang telah dilakukan (lihat Ullul, dkk, 2016). Cara yang dilakukan Ibu Vitri mengevaluasi hasil belajar kelompok adalah dengan memberikan penilaian tugas melalui lembar kerja murid atau tes serta penugasan berupa produk seperti karya atau non tes (lihat Anthony, dalam Arifin, 2012).

Selain menggunakan lembar kerja murid dan produk, Ibu Vitri mengevaluasi dengan memberikan tes lisan di akhir pembelajaran (lihat Maman, 2017). Tes ini dilakukan di akhir pembelajaran dan dijawab langsung oleh murid pada saat guru selesai mengeluarkan pertanyaannya. Pertanyaan yang diberikan oleh Ibu Vitri mengarah pada kesimpulan pembelajaran. Peneliti setuju bahwa dengan memberikan kesimpulan di akhir pembelajaran, guru dapat membantu murid memahami inti materi yang telah dipelajari (lihat Mulyasa, 2010).

Tes lisan yang diberikan oleh Ibu Vitri termasuk tes lisan bebas. Dalam tes lisan bebas, guru tidak memerlukan panduan secara tertulis untuk menyusun pertanyaan yang diberikan kepada murid (lihat Thoha, dalam Vivi, 2010). Menurut peneliti tes lisan baik dilakukan karena tes lisan membatu murid untuk berani berpendapat (lihat Salamah, 2018).

Dalam pelaksanaan tes lisan, Ibu Vitri memberikan pertanyaan kepada beberapa orang murid saja. Bagi peneliti, hal ini perlu diperbaiki karena dalam melaksanakan tes lisan, pertanyaan yang diberikan oleh guru harus bersifat menyebar. Hal ini bertujuan untuk mendorong murid agar mau berusaha menemukan jawaban dari pertanyaan yang disampaikan (lihat Wahid, 2010). 
Tahap terakhir yang dilakukan oleh Ibu Vitri adalah pemberian penghargaan. Pemberian penghargaan membuat murid termotivasi untuk belajar dengan lebih baik, serta mengapresiasi usaha yang dilakukan oleh murid (lihat Widiasmoro, 2015). Selain itu, menurut peneliti pemberian penghargaan dapat memotivasi murid dalam belajar sehingga murid semakin giat untuk aktif dan produktif di dalam kelas (lihat Purwanto, 2011, dan Rusman, 2014).

Tantangan penerapan model pembelajaran kooperatif tipe STAD adalah saat membentuk kelompok belajar. Hal ini terjadi karena setiap murid memiliki keunikan, kelebihan, dan kebutuhan yang beragam, sehingga tidak semua murid dapat dikelompokkan menjadi satu kelompok tertentu. Strategi untuk meminimalisir kendala tersebut adalah melakukan pengubahan kelompok belajar dengan melibatkan peran murid. Tujuannya untuk membekali keterampilan memecahkan masalah (lihat Mislinawati, 2019).

\section{KESIMPULAN DAN SARAN}

\subsection{Kesimpulan}

Kesimpulan penelitian ini yaitu diperlukan penambahan 2 tahap penerapan model pembelajaran koopeartif tipe STAD, yaitu pembagian rubrik penilaian dan form penilaian sebaya, serta dengan memberikan pendidikan karakter Kristen untuk membuat Matematika menjadi kelas yang efektif dan bermakna di SD Kristen "X" Surabaya.

\subsection{Saran}

Beberapa saran yang dapat peneliti berikan adalah sebagai berikut : a. Bagi guru Kristen sebaiknya lebih menekankan nilai Kekristenan ketika mengajar Matematika, terkhusus terkait dengan tujuan dasar murid belajar Matematika yaitu untuk semakin mengenal Tuhan. Selain itu, dengan belajar Matematika, murid semakin menyadari bahwa mereka memerlukan Tuhan sebagai sumber hikmat dan pengetahuan.

b. Sebaiknya guru Kristen menggunakan pertanyaan yang bersifat menyebar ketika memberikan tes lisan kepada murid sebab hal ini dapat mendorong murid untuk berusaha menemukan jawaban dari pertanyaan yang disampaikan.

c. Bagi peneliti selanjutnya, disarankan untuk mempertimbangkan kekurangan yang ada pada penelitian ini seperti halnya pada proses wawancara yang dilakukan secara online, sehingga ada beberapa bagian yang tidak terlalu jelas terdengar. Selain itu sebaiknya guru juga mempertimbangkan dalamnya informasi yang akan diulas, sehingga pada penelitian yang akan datang, informasi yang diberikan atau ditambahkan dapat semakin banyak dan mendalam.

\section{DAFTAR REFERENSI}

Achdiyat, M. (2017). Evaluasi dalam pembelajaran. Tangerang, Indonesia: Pustaka Mandiri.

Al-Tabany, T. I. B. (2017). Mendesain model pembelajaran inovatif, progresif, dan kontekstual: Konsep, landansan, dan implementasinya pada kurikulum 2013 (kurikulum tematik integratif/KTI). Jakarta, Indonesia: Kharisma Putra Utama.

Anita, L. (2003). Cooperative learning mempraktikkan cooperative learning di ruang-. ruang kelas. Jakarta, Indonesia: PT. Grasindo Widia Sarana.Berkhof, L., \& Til, C. Van. (2010). Foundation Christian Education. $3^{\text {rd }}$ ed. Jakarta, Indonesia: 
Momentum.

Brummelen, H. V. (2009). Berjalan dengan Tuhan di dalam kelas. Jakarta, Indonesia: Universitas Pelita Harapan Press.

Brummlen, H. V. (2009). Walking with God in the classroom: Christian approaches to teaching and learning. $3^{\text {rd }}$ ed. USA: Purposeful design publications ACSI.

Clark, R.E., JohnSon, L., \& Sloat, A.K. (1991). Christian education. Choicago, USA: Moody Publishers.

Curran, L. (1994). Lessons for little ones: Mathematics and cooperative learning. San Juan Capistrano, USA: Kagan Publishing.

Dimyati \& Mudjiono. (2009). Belajar dan pembelajaran. Jakarta, Indonesia: Rineka Cipta.

Gora, R. (2019). Riset kualitatif public relations. Surabaya, Indonesia: Jakad Publishing.

Gangel, K. O., (2003). Biblical foundation of education. In ACSI. (chap.5). Foundations Of Christian School Education. Corolado Springs, USA: Association Of Christian Education School International.

Gintings, A. (2010). Esensi praktis belajar dan pembelajaran.

Bandung, Indonesia: Humaniora Utama Press.

Hamdani. (2011). Strategi belajar mengajar. Bandung, Indonesia: Pustaka Setia.

Handayani, S. (2019). Pembelajaran speaking tipe STAD yang interaktif fun game berbasis karakter. Ponorogo, Indonesia: Uwais Inspirasi Indonesia.

Hardiansyah, H. (2015).
Wawancara, observasi, dan focus groups: Sebagai instrumen penggilan data kualitatif. Jakarta, Indonesia: Raja Grafindo Persada.

Hartatik, S. (2016). Peningkatan sikap pluralitas dan hasil belajar PKN melalui penerapan problem-based learning (PBL) bagi siswa kelas xii-ipa 5 semester gasal SMA Negeri 5 Surakarta tahun 2016/2017. Jurnal Pendidikan Dwija Utama: Forum Komunikasi Pengembangan Profesi Pendidik Kota Surakarta, 8 (36), 19799098. Retrieved from https://books.google.co.id/books/about/ JUrnal_Pendidikan_Dwija_Utama.htm 1?id=VJWDDwAAQBAJ\&printsec $=\mathrm{fr}$ ontcover\&source=kp_read_button\&red ir_esc $=\mathrm{y}$.

Hidayat, A. (2018). Meta analisis: Pentingnya self dan peer assesment dalam pembelajaran. Jurnal Basicedu: Research \& Learning In Elementary Education. 2 (1), 95-101. doi: 10.31004/basicedu.v2i1.30.

Ibrahim, M. (2000). Pembelajaran kooperatif. Surabaya, Indonesia: Universitas Surabaya.

Isjoni. (2010). Cooperative learning, efektifitas pembelajaran kelompok. Bandung, Indonesia: Alfabeta.

Jacobs, G. M., Lee, G. S., \& Ball, J. (1997). Learning cooperative learning via cooperative learning: A sourcebook of lesson plants for teacher education on cooperative learning. San Clemente, USA: Kagan Publishing.

Jaeng, M. (2016). Pendidikan karakter melalui pendidikan matematika. AKSIOMA Jurnal Pendidikan Matematika, 5(3). Retrieved from http://jurnal.untad.ac.id/jurnal/index.ph p/AKSIOMA/article/download/8614/6 834.

Lewis, B. A. (2004). Character building untuk anak-anak. Batam, Indonesia: Karisma Publishing Group.

Lewis, B. A. (2004). Character building 
untuk remaja. Batam, Indonesia: Karisma Publishing Group.

Lie, A. (2002). Cooperative learning: Mempraktikkan cooperative learning di ruangruang kelas. Jakarta, Indonesia: Grasindo.

Marta, E. D. (2016). Implementasi pemberian reward kepada siswa SD Muhammadiyah Bantul Kota (Undergraduate thesis, Universitas Negeri Yogyakarta, 2016). Retrieved from https://eprints.uny.ac.id/37922/1 /Erni\%20Dwi\%20Marta.pdf.

Maulana., Djuanda, D., Hanifah, N., Sujana, A., Gusryani, D., Aeni, A. N., Julia., Jayadinata, A. K., Irawati, R., \& Lichteria, R. P. (2015). Ragam model pembelajaran di sekolah dasar. $2^{\text {nd }}$ ed. Sumedang, Indonesia: UPI Sumedang Press.

Miles, B. (1992). Analisis data kualitatif: buku sumber tentang metode-metode baru. $1^{\text {st }}$ ed. Jakarta, Indoneia: Universitas Indonesia.

Moleong, L. J. (2009). Metodologi penelitian kualitatif. Bandung, Indonesia: Remaja Rosdakarya.

Mumtahanah, F. (2018). Implementasi strategi pembelajaran kooperatif tipe student team achievement division (STAD) pada mata pelajaran matematika di kelas $v$ MI Ya Bakii Welahan Wetan Kecamatan Adipala Kabupaten Cilacap (Undergraduate thesis, IAIN Purwokerto, 2018). Retrieved from http://repository.iainpurwokerto. ac.id/4170/.

Nadeak, E. H. \& Hidayat, D. (2017). Karakteristik pendidikan yang menebus di suatu sekolah kristen. POLYGOT: A Journal of

Language, Literature, Culture, and Education. 13(2). 87-97. Retrieved from

https://ojs.uph.edu/index.php/PJI/articl e/download/439.

Nasryah, C. E., \& Rahman, A. A. (2016).

Penerapan model pembelajaran

kooperatif tipe student teams achievement division (STAD) pada materi bangun datar segi empat di kelas 5 SD Negeri Inpres 115495 Sisumut Kota Pinang. Jurnal Bina Gogik. 3(1). 25-34. Retrieved from https://www.ejournal.stkipbbm.ac.id/in dex.php/pgsd/article/view/24.

Nurdin, I., \& Hartati, S. (2019). Metodologi penelitian sosial. Surabaya, Indonesia: Media Sahabat Cendekia.

Pane, M. L. (2019). Tantangan dan kesempatan integrasi Alkitab (Undergraduate thesis, Universitas Pelita Harapan, 2019). Retrieved from http://repository.uph.edu/5787/5/e\%20 Kajian\%20Filosofis\%20Pendidikan.pd f.

Prastowo, A. (2011). Panduan kreatif membuat bahan ajar inovatif. Yogyakarta, Indonesia: Diva Press.

Purwanto, N. (2011). Ilmu pendidikan teoretis dan praktis. Bandung, Indonesia: PT Remaja Rosdakarya.

Puspitawati, S. (2016). Pengantar interaksi belajar mengajar yang efektif. Surabaya, Indonesia: BPK Gunung Mulia.

Powers, B. P. P. (1996).Christian education hand book: A reviced and completely updated edition. USA: Broadman and Holman Publishers.

Raco, J. (2010). Metode penelitian kualitatif: Jenis, karakteristik dan keunggulannya. Jakarta, Indonesia: Grasindo.

Rianawati. (2014). Implementasi nilai-nilai karakter pada mata pelajaran. Pontianak, Indonesia: IAIN Pontianak 
Press.

Rusman. (2014). Model-model pembelajaran mengembangkan profesionalisme guru. Jakarta, Indonesia: Rajawali Pers.

Sairin, W. (2006). Identitas dan ciri khas pendidikan kristen di Indonesia: Antara konseptual dan operasional. $2^{\text {nd }}$ ed. Jakarta, Indonesia: BPK Gunung Mulia.

Sanjaya, W. (2010). Kurikulum dan pembelajaran: Teori dan praktek pengembangan kurikulum KTSP. Jakarta, Indonesia: Kencana.

Sanjaya, W. (2014). Strategi pembelajaran berorientasi standar proes pendidikan. Jakarta, Indonesia: Kencana Prenamedia Group.

Saragih, M. J., Hidayat, D., \& Tamba, K. P. (2019). Implikasi pendidikan yang berpusat pada Kristus dalam kelas matematika (The implications of Christcenter education for mathematics classes). JOHME: Journal of Holistic Mathematics Education. 2(2). 97-107. doi: https://dx.doi.org/10.19166/joh me.v2i2.1695.

Sardiman, A. M. (2014). Interaksi dan motivasi belajar mengajar. Jakarta, Indonesia: Raja Grafindo Persada.

Sarosa, S. (2012). Penelitian kualitatif dasar-dasar. Jakarta, Indonesia: Indeks.

Seymour, J. L. (2016). Memetakan pendidikan kristiani: Pendekatan-pendekatan menuju pembelajaran jemaat. Jakarta, Indonesia: BPK Gunung Mulia.

Shipton,W., Coetzee, E., \& Takeuchi, R. (2013). Worlview and christian education. One Fullerton, Singapura: Partridge

\section{Singapore.}

Sidjabat, B. S. (1994). Strategi pendidikan kristen: Suatu tinjauan teologisfilosofis. Yogyakarta, Indonesia: Yayasan Andi.

Sihalohol, G. T., Sitompul, H., \& Appulembang, O. C. (2020). Peran guru kristen dalam meningkatkan keaktifan siswa pada proses pembelajaran matematika di sekolah kristen (The role of christian teachers in improving active learning in mathematics in a christian school). JOHME: Journal of Holistic Mathematics Education. 3(2). 200-215. doi:

https://dx.doi.org/10.19166/johme.v3i2 .1988.

Simatupang, H. (2015). Definisi theologi praktis kristen sesuai kerabian Yesus dan payung bagi pendidikan kristiani. Yogyakarta, Indonesia: Penerbit Andi.

Soekarmini. (Ed). (2016). Segalanya menjadi baru. Jakarta, Indonesia: Lembaga Alkitab Indonesia.

Sugiyono. (2007). Metode penelitian kuantitatif, kualitatif dan $R \& D$. Bandung, Indonesia: Afabeta.

Sugiyanto. (2008). Model-Model pembelajaran inovatif. Surakarta, Indonesia: Panitia.

Sugiyono. (2011). Metode penelitian kuantitatif, kualitatif dan $R \& D$. Bandung, Indonesia: Afabeta.

Sugiyono. (2013). Metode penelitian pendidikan (Pendekatan kuantitatif, kualitatif, dan $R \& D)$. Bandung, Indonesia: Alfabeta.

Suryosubroto. (1990). Tatalaksana kurikulum. Jakarta, Indonesia: Rineka Cipta.

Susanti, Y., Wahjoedi, \& Utaya, S. (2017). Peningkatan aktifitas dan hasil belajar melalui pembelajaran kooperatif tipe STAD. Jurnal Pendidikan: Teori, Penelitian, dan Pengembangan, 2(5), 661-666. Retrieved from 
http://journal.um.ac.id/index.ph p/jptpp/article/view/9160/4422.

Trinto. (2009). Mendisain model pembelajaran inovatif progresif. Jakarta, Indonesia: Kencana Prenamedia Group.

Tarigan, M. S. (2019). Kebenaran Allah sebagai dasar pendidikan kristen (God's truth as foundation of Christian education). JOHME: Journal of Holistic Mathematics Education. 3(1). 80-95. doi: dx.doi.org/10.19166/johme.v3i1 .1684 .

Uluul., Degeng, I. N. S., \& Widiati, U. (2016). Pelaksanaan membuka dan menutup pelajaran oleh guru kelas 1 sekolah dasar. Jurnal Pendidikan: Teori, Penelitian, dan Pengembangan. 8 (9), 1730-1734. Retrieved from http://journal.um.ac.id/index.ph p/jptpp/article/download/6738/2 931.

Wesley, A., \& Davidson, N. (1990). Cooperative learning mathematics: A handbook for teachers. California: AddisonWesley, Inc.

Wibowo, T. G. (2016). Menjadi guru kreatif. Bekasi, Indonesia: Penerbit Media Maxima.

Widiasworo, E. (2015). 19 kiat sukses membangkitkan motivasi belajar peserta didik.

Yogyakarta, Indonesia: ArrRuzz Media.

Wijayanti, A. (2017). EfektiSekolah Dasar Kristen " $X$ "

Surabayas self assessment dan peer assessment dalam pembentukan karakter siswa. Jurnal Realita. 15 (2). Retrieved from https://www.jurnal.iainkediri.ac. id/index.php/realita/article/dow nload/482/311.

Yatmoko, F. D. (2018). Penerapan model pembelajaran kooperatif tipe STAD untuk meningkatkan kerjasama dan hasil belajar matematika materi volume kubus dan balok kelas $v$ SDK Murukan tahun pelajaran 2017/2018 (Undergraduate thesis, Universitas Sanata Dharma, 2018). Retrieved from http://repository.usd.ac.id/31392/ 